\title{
Work-related teaching and learning methods to foster generic skills in Higher Education. An Italian experience
}

\author{
Daniela Frison, Concetta Tino, Jonathan W. Tyner, and Monica Fedeli*
}

doi: http://dx.doi.org/10.18543/tjhe-4(1)-2016pp145-167

\begin{abstract}
Within the framework of modernisation of higher education systems in Europe, universities are invited to go beyond a knowledge-based perspective focused on disciplinary approaches and to be more concentrated on encouraging generic skills to deal with today's complex and unpredictable career paths. The literature about Work-Related Learning and Work-Integrated Learning offers evidence to research regarding contributions of work-related experiences to the development of generic skills. The first part of the article presents a literature review carried out following the matching among three main keywords: work-related learning, generic skills, and higher education. Resources focused on the integration/ teaching of generic skills in formal curriculum or in co-curriculum work-related activities and they were collected in order to explore the link between work-related learning in higher education and the development of generic skills. The focus is to identify valuable considerations to improve teaching strategies and methods. The second part presents an Italian work-related experience developed within the course of "Organizational Intervention Research Methods," which involved 22 master's degree students. The work-related assignment will be described in addition to the content analysis process of the 22 collected texts and the findings about the development of generic skills.
\end{abstract}

Daniela Frison (daniela.frison@unipd.it), PhD in Educational Sciences, is a Post-Doc Researcher at the Department of Philosophy, Sociology, Education, and Applied Psychology, University of Padova (Italy).

Concetta Tino (concettatino8@gmail.com), is a doctoral student at University of Padova (Italy). Her main fields of research are the School-Work Alternation programs as part of WorkBased Learning experiences, and the training of teachers-tutor involved in supporting students in the transition school-to-work.

Jonathan W. Tyner (jonathantyner@txstate.edu), is a doctoral student in the Adult, Professional, and Community Education program at Texas State University (USA). His current position is the international engagement specialist for Texas State University in San Marcos, Texas.

Monica Fedeli (monica.fedeli@unipd.it), PhD in Teaching and Learning and Special Education, is currently Associate Professor at University of Padova (Italy).

More information about the authors is provided at the end of this article (after the bibliography list). 
Keywords: work-related learning; generic skills; higher education; teaching and learning methods; university-business cooperation.

\section{Introduction}

Within the framework of modernisation of the European Higher Education system, universities are invited to go beyond a knowledge-based perspective focused on disciplinary approaches, and to encourage generic skills and creative learning outcomes such as complex thinking, social skills, participatory learning, and personal shaping of knowledge. ${ }^{1}$ Furthermore, curricula should be developed through partnerships among teaching staff, students, graduates, and labour market actors in order to drawing on effective teaching and learning methods which could mend the gap between study and work. ${ }^{2}$ European documents ${ }^{3}$ suggest strategies and approaches such as dialogue and cooperation with companies and organizations, in order to expose teachers and learners to real life situations, challenges, and cases and offer students the opportunity to acquire relevant skills that enhance their employability. ${ }^{4}$

The focus on university-business dialogue and cooperation with the world of work, ${ }^{5}$ in addition to teaching and learning methods, links the academic setting with a "real" environment, an authentic professional work setting that allows students to observe actual work occurring in a workplace. This "real" environment refers to what is mentioned in North American literature as Work-Related Learning ${ }^{6}$ and in Australian literature as Work-

${ }^{1}$ European Commission, Modernisation of Higher Education, Report on Improving the quality of teaching and learning in Europe's higher education institutions (Luxembourg: Publications Office of the European Union 2013), accessed July 22, 2016, http://ec.europa.eu/ dgs/education_culture/repository/education/library/reports/modernisation_en.pdf.

${ }^{2}$ European Commission, Modernisation of Higher Education.

${ }^{3}$ Commission of the European Communities, A new partnership for the modernisation of universities: the EU Forum for University Business Dialogue, (2009), accessed July 22, 2016, http://ec.europa.eu/transparency/regdoc/recherche.cfm?C=it; European Commission, Supporting growth and jobs - an agenda for the modernisation of Europe's higher education systems, (2011), accessed July 22, 2016, http://ec.europa.eu/education/library/policy/ modernisation_en.pdf; Technopolis, Education in the Knowledge Triangle, (2012), accessed July 22, 2016, http://www.mondragon.edu/en/international/files/OF\%2035\%201613\%20 Draft\%20final\%20report\%20and\%20case\%20studies\%20121025-1.pdf.

${ }^{4}$ European Commission, Modernisation of Higher Education.

${ }^{5}$ Commission of the European Communities, A new partnership.

${ }^{6}$ John M. Dirkx, "Work-Related Learning in the United States: Past Practices, Paradigm Shifts, and Policies of Partnerships," in The Sage Handbook of Workplace Learning (2011): 293-306. 
Integrated Learning. ${ }^{7}$ Indeed, the two terms both concern the integration between educational experience (such as formal course) and practical one (such as work) in order to create meaningful benefits for students, organizations, and other stakeholders.

\section{Definition of terms}

A literature review based on 18 conceptual (7) and empirical (11) articles selected among 40 European, US, and Australian resources guided the research group to clarify terms, theoretical orientations, and practical implications about work-related teaching and learning methods to improve generic skills. ${ }^{8}$ The articles have been selected according to the matching among three main key words: work-related (or integrated) learning, generic (or soft) skills, and higher education. Using these criteria, resources were collected on the integration/teaching of generic skills in formal curriculum or in co-curriculum work-related activities in order to explore the link between work-related learning in higher education and the development of generic skills as well as to identify valuable considerations to improve teaching strategies and methods in the formal setting. In this way, the research group has excluded papers related to workplace or work-based learning, more focused on informal and non-formal learning and on activities outside the academic setting which are carried out into the workplace (internship, service learning, etc.). Suitable literature was identified using Google Scholar and relevant databases were searched by using the AIRE (Integrated Access to Electronic Resources) Portal of the Padua University in order to retrieve electronic resources from the University Library System.

${ }^{7}$ Indra Abeysekera, "Issues relating to designing a Work-Integrated Learning (WIL) program in an undergraduate accounting degree program and its implications for the curriculum," Asia-Pacific Journal of Cooperative Education 7, no. 1 (2006): 7-15; Lesley Cooper, Janice Orrell, and Margaret Bowden, Work integrated learning: A guide to effective practice (Routledge, 2010); Phil Gardner and Kenneth R. Bartkus, "What's in a name? A reference guide to work-education experiences," Asia-Pacific Journal of Cooperative Education 15, no. 1 (2014): 37-54.

${ }^{8}$ Daniela Frison, "Esperienza e apprendimento: verso una didattica work-related", in Coinvolgere per apprendere. Metodi e tecniche partecipative per la formazione ed. Fedeli Monica, Grion Valentina and Frison Daniela (Lecce: Pensa Multimedia, 2016); Daniela Frison, Monica Fedeli, and Edward W. Taylor, "Work-Related Learning: a survey on Teaching and Learning Methods in the Italian Higher Education System," ICERI 2015 Proceedings (2015): 8393-8401. 
First, the collected resources provide different definitions in order to clarify the term Work-Related Learning (WRL). For example, Coll and colleagues ${ }^{9}$ define Work-Integrated Learning (WIL), more used in the Australian context, as "an educational strategy in which students undergo conventional academic learning within an educational institution and combine this with some time spent in a workplace relevant to their program of study and career aims". Beyond this focus, McLennan \& Keating ${ }^{10}$ underline that WIL is a teaching and learning approach that, "has the potential to provide a rich, active and contextualized learning experience for students which contributes to their engagement in learning". Around these aims, Gardner and Bartkus have mapped a variety of alternative names that have been developed to refer to the integration between formal context and workplace: ${ }^{11}$ Cooperative and Work-Integrated Education includes community/service focus (service learning, cooperative education, and community-based learning) ${ }^{12}$; Career and Technical Education, more used in US and Canada, identifies instruction aims heading at developing core workplace competences and specific skills in different occupational areas ${ }^{13}$ and finally Experiential Education takes students into the community. ${ }^{14}$

Furthermore, in the North American context, Dirkx ${ }^{15}$ extensively defines Work-Related Learning as learning which occurs "in educational preparation programs apart from the workplace, in formal and informal learning within the workplace, and in continuing education and professional development programs offered outside of the workplace".

As anticipated, under this wider definition, the research group has focused its attention specifically on the academic setting and work-related strategies such as approaches and methods that are integrated into the curriculum.

${ }^{9}$ Richard K. Coll et al., "Putting the 'integrated' in work-integrated learning," World Association of Co-operative Education Asia Pacific 2008 Conference: Work Integrated Learning (WIL): Transforming Futures, Practice... Pedagogy... Partnerships, (2008): 112.

${ }^{10}$ Belinda McLennan and Shay Keating, "Work-integrated learning (WIL) in Australian universities: The challenges of mainstreaming WIL," ALTC NAGCAS National Symposium, (2008): 4.

11 Gardner and Bartkus, "What's in a name?".

12 Richard K. Coll and Karsten E. Zegwaard, "Perceptions of desirable graduate competencies for science and technology new graduates," Research in Science \& Technological Education 24, no. 1 (2006): 29-58.

${ }_{13}$ John L. Scott and Michelle Sarkees-Wircenski, Overview of Vocational and Applied Technology Education (Homewood Illinois: American Technical Publishers, 2004).

14 Janet Eyler, "The power of experiential education," Liberal Education 95, no. 4 (2009).

15 Dirkx, "Work-Related Learning," 294. 
Starting from this analysis orientation, a specific focus has been devoted to the link between WRL (or WIL) and generic skills. Indeed, the development of generic skills is recognized among the main goals of WRL/ WIL experiences. ${ }^{16}$ In their research, Freudenberg, Brimble, and Cameron propose a Professional Development Program (PDP) in order to encourage knowledge and skill areas as "social interaction (networking), selfmanagement (time-management, personal planning), learning and adaptability, problem-solving, conceptualize and analyse, work in teams, speak to an audience (to prepare a presentation), search for information (read databases, surf the net), write essays (or a CV, a letter of presentation), and the ability to identify and define professional goals (understand the different roles and the needs of the organizations)".${ }^{17}$ Also Coll and colleagues highlight that a key purpose of WIL is to provide graduates with a skill set coherent with the request of potential employers. ${ }^{18}$ Despite this emphasized focus on the link between work-related activities and the improvement of generic skills, literature on the topic underlines the difficulty for Higher Education systems to provide students with workplace skills, especially the generic ones. ${ }^{19}$

Concerning generic skills, De Villiers ${ }^{20}$ underlines that it is not easy to define these skills because the definition and concept differs across discipline,

${ }^{16}$ Atchison Mary et al., Work integrated learning paper (Melbourne: RMIT University, 2002); Coll, "Putting the 'integrated' in work-integrated learning"; Crebert Gay et al., "Developing generic skills at university, during work placement and in employment: graduates' perceptions," Higher Education Research \& Development 23, no. 2 (2004): 147-165; Evelyn Shyamala Devadason, Thirunaukarasu Subramaniam, and Esther Gnanamalar Sarojini Daniel, "Final year undergraduates' perceptions of the integration of soft skills in the formal curriculum: a survey of Malaysian public universities," Asia Pacific Education Review 11, no. 3 (2010): 321-348; Brett Freudenberg, Mark Brimble, and Craig Cameron, "WIL and generic skill development: The development of business students' generic skills through workintegrated learning," Asia-Pacific Journal of cooperative education 12, no. 2 (2011): 79-93; Nava Subramaniam and Brett Freudenberg, "Preparing accounting students for success in the professional environment: Enhancing self-efficacy through a work integrated learning programme," Asia-Pacific journal of cooperative education 8, no. 1 (2007): 77-92.

${ }^{17}$ Freudenberg, Brimble, and Cameron, "WIL and generic skill development," 173.

18 Coll et al., "Putting the 'integrated' in work-integrated learning."

19 Noel Burchell, Dave Hodges, and L. Rainsbury, "What competencies do business graduates require? Perspectives of New Zealand stakeholders," Journal of Cooperative Education 35, no. 2-3 (2000): 11-20; Coll et al., "Putting the 'integrated' in work-integrated learning;" Coll and Zegwaard, "Perceptions of desirable graduate competencies."

20 Rouxelle De Villiers, "The incorporation of soft skills into accounting curricula: preparing accounting graduates for their unpredictable futures," Meditari Accountancy Research 18, no. 2 (2010): 1-22. 
context, and sometimes country. Bennet and colleagues ${ }^{21}$ define them as skills which "support any discipline (generic), and which can be transferred to a range of contexts, in higher education or the workplace". Generic skills are also defined as "those transferable skills which are essential for employability at some level for most" 22 and, as Bridgstock ${ }^{23}$ affirms, these skills have also been defined as core skills, key competencies, transferable skills, or underpinning skills.

Several empirical researchers were aimed at collecting the employers' point of view ${ }^{24}$ concerning both the definition and the different traits of generic skills or the students' workplace experiences. ${ }^{25}$ Less empirical studies have been carried out in order to explore the integration of generic skills in the higher education setting. Concerning this issue, the research group mapped resources related to the development of generic skills by means of work-placement programs ${ }^{26}$ activities integrated into the curriculum, ${ }^{27}$ and specific teaching and learning methods ${ }^{28}$ across different

${ }^{21}$ Neville Bennett, Elisabeth Dunne, and Clive Carré, "Patterns of core and generic skill provision in higher education," Higher education 37, no. 1 (1999): 71-93.

${ }^{22}$ Peter Kearns, Generic Skills for the New Economy. Review of Research (Leabrook: National Centre for Vocational Education Research, 2001).

${ }^{23}$ Ruth Bridgstock, “The graduate attributes we've overlooked: Enhancing graduate employability through career management skills," Higher Education Research \& Development 28, no. 1 (2009): 31-44.

${ }^{24}$ Bridgstock, "The graduate attributes we've overlooked;" Melvin R. Weber et al., "An exploratory study identifying soft skill competencies in entry-level managers," Tourism and hospitality Research 9, no. 4 (2009): 353-361.

${ }^{25}$ Coll et al., "Putting the 'integrated' in work-integrated learning;" Sally Sambrook, "Factors influencing the context and process of work-related learning: Synthesizing findings from two research projects," Human Resource Development International 8, no. 1 (2005): 101-119.

${ }^{26}$ Crebert, "Developing generic skills at university."

27 Devadason, Subramaniam, and Daniel, "Final year undergraduates' perceptions;" De Villiers, "The incorporation of soft skills into accounting curricula;" Ian Drummond, Iain Nixon, and John Wiltshire, "Personal transferable skills in higher education: The problems of implementing good practice," Quality assurance in education 6, no. 1 (1998): 19-27; Freudenberg, Brimble and Cameron, "WIL and generic skill development;" Roselina Shakir, "Soft skills at the Malaysian institutes of higher learning," Asia Pacific Education Review 10, no. 3 (2009): 309-315.

${ }^{28}$ James Cannan, "Practice based learning: exploring current models used for real world learning at a "dual sector tertiary institution," WACE Asia Pacific Conference E-Proceedings (2008); Coll et al., "Putting the 'integrated' in work-integrated learning"; Devadason, Subramaniam and Daniel, "Final year undergraduates' perceptions;" Freudenberg, Brimble and Cameron, "WIL and generic skill development;" Scott Lee, "A comparison of student perceptions of learning in their co-op and internship experiences and the classroom environment: A study of hospitality management students" (Diss., University of Central Florida Orlando, 
disciplinary sectors. For example, Dummond, Nixon, and Wiltshir ${ }^{29}$ describe embedded or integrated development strategies where skills are "developed within the curriculum (randomly interspersed, core modules, mapped skills with no progression, mapped skills with progression, or project-based development)", whilst Devadason, Subramaniam, and Daniel ${ }^{30}$ describe as "development of soft skills based on formal teaching and learning activities". Otherwise, generic skills could be improved by means of parallel (or standalone) development "in freestanding modules, which are not integrated into the curriculum". ${ }^{31}$ These are also defined as "bolt-on" courses, such as "public speaking" or "critical thinking" 32 or co-curriculum programs that are especially conceived to improve generic skills.

Therefore, in this contribution the integration of generic skills in the curriculum becomes the joining link between WRL in the formal curriculum and teaching and learning activities.

Within this framework of WRL/WIL, the explored literature offers a wide variety of models and categorizations of generic (often mentioned as soft) skills in higher education programs. De Villiers ${ }^{33}$ identifies two conceptual domains of necessary skills that are specific for business graduates and professionals at all levels: 1) technical skills and 2) the emotional intelligence. These skills include negotiation, diversity sensitivity, social complexity, social judgement, networking, flexibility and adaptability.

In the Malaysian higher education system, the generic skills include: communication skills in English, critical thinking and problem-solving, team-work, lifelong learning and information management, entrepreneurial skills, moral and professional ethics, and leadership..$^{34}$

Other generic skills categorizations are included in wider models related to graduates' attributes and work-readiness. This is the case of the conceptual model of graduate attributes for employability developed by Bridgstock ${ }^{35}$ and referring to: career management skills composed by self-management skills and career building skills, discipline-specific skills, originated in

Florida, 2006); Chynette Nealy, "Integrating soft skills through active learning in the management classroom," Journal of College Teaching \& Learning (TLC) 2, no. 4 (2011): 1-6.

${ }_{29}$ Drummond, Nixon, and Wiltshire, "Personal transferable skills in higher education," 21.

${ }^{30}$ Devadason, Subramaniam, and Daniel, "Final year undergraduates' perceptions," 325.

${ }^{31}$ Drummond, Nixon, and Wiltshire, "Personal transferable skills in higher education," 21.

32 Devadason, Subramaniam, and Daniel, "Final year undergraduates' perceptions."

${ }^{33}$ De Villiers, "The incorporation of soft skills into accounting curricula."

${ }^{34}$ Devadason, Subramaniam, and Daniel, "Final year undergraduates' perceptions;" Shakir, "Soft skills at the Malaysian institutes of higher learning."

${ }^{35}$ Bridgstock, "The graduate attributes we've overlooked." 
specific domains, disciplines or subject matter areas, generic skills, and underpinning traits and dispositions. Within this approach, Litchfield and Nettleton ${ }^{36}$ propose a set of key graduate attribute descriptors including: global perspective, communication capacity, ability to work well in a team, ability to apply knowledge, and creative problem-solving and critical thinking skills.

Despite the richness of models and definitions, there is consistent lack of literature, methods, and instructional approaches for faculty to foster connections between higher education and the world of work in order to encourage generic skills and "work-readiness". Few methodological advices are available on how to develop work-related strategies in class and to promote connections between course contents and the related professions or support activities in cooperation with organizations in order to improve generic skills.

This study proposes a work-related activity specially designed to give students the opportunity to spend time in a "real" professional environment that is relevant to their study program and career aims by completing a particular assignment related to course contents. According to the literature mentioned earlier, the development of generic skills is recognized as one of the main goals of WRL activities, the research questions guiding the study was the following: 1) do students who are involved in the WR assignment recognize and reflect on the development of generic skills as an outcome for the WRL experience? And 2) according to the students' perspective, what are the generic skills encouraged by the specific WR proposed assignment?

\section{Methods}

The work-related assignment was designed and carried out during the Academic Year 2014/2015 within the course of "Organizational InterventionResearch Methods" (master study program in Lifelong and Continuing Education, University of Padua) in accordance with a company placed in the Italian Veneto territory.

22 Italian students (1 M and $21 \mathrm{~F})$ attending the first year of the master program were involved in the study. The work-related (WR) assignment asked students to identify, in pairs (11 couples), the main values of the organizational culture of a company, starting from the observation of its

\footnotetext{
${ }^{36}$ Litchfield and Nettleton, "Work-ready wiki."
} 
spaces. As Merriam and Tisdell ${ }^{37}$ underline, the observation of the physical setting focuses on these aspects: "what is the physical environment like? What is the context? What kinds of behaviours is the setting designed for? How is space allocated? What objects, resources, technologies are in the setting?". The hypothesis which guided the assignment was the following: the arrangement of spaces and the way of using them within a company are relevant indicators of the organizational values which inspire the behaviours of its actors and its organizational culture. ${ }^{38}$ Collaboratively, teachers and organizational representatives (belonging to the Human Resources Department) arranged a 4 hours business visit in order to allow students to move within the company, observing inside and outside, architecture and interiors, through the means of a provided observation grid to carry out a structured observation of the physical environment. ${ }^{39}$

At the end of the company-visit experience, the 11 pairs of students were asked to complete two different tasks:

1. Working in pairs, they wrote a report concerning the observed organizational culture. The report was addressed to the Human Resources Department of the company. The pairs were invited to add, at the end of the report, an explanation about the strategy followed to manage the observation assignment from a methodological point of view (How? Alone or with the support of the colleague? Sharing with the colleague the observation strategy from the beginning or only at the end? Observing without the grid and using the grid at the end or using it from the beginning of the observation?).

2. At the end of the first in pairs section, each student wrote an individual text, based on her/his own personal reflections about the work-related experience. This individual reflection encouraged students to think about strengths, difficulties, challenges, and feelings related to the WR assignment and to focus on the personal management of the activity, once more from a methodological point of view.

This paper focuses on the content analysis of the pair and individual texts, submitted online by the students through the University Content Management System.

${ }^{37}$ Sharan B. Merriam and Elizabeth J. Tisdell, Qualitative research: A guide to design and implementation(John Wiley \& Sons, 2015), 141.

${ }_{38}$ Aberto Munari, "L'osservazione sistematica e strutturata della gestione degli spazi di un'organizzazione" (Unpublished manuscript, University of Padova, Italy, 2013).

39 Munari, "L'osservazione sistematica e strutturata." 


\section{Data Analysis and Findings}

The 22 collected individual texts and the 11 pair texts were analysed employing qualitative data analysis and the research software Atlas.ti 7.0. Texts were uploaded into the software as primary documents (PDocs) made up of two different Hermeneutic Units (HUs), a sort of containers of PDocs, quotations and codes. The first HU gathered 22 individual texts and the second one 11 collaborative reflective parts. The coding process was carried out through the assignment of pre-codes and codes to the texts and, further, through the aggregation in code families. The pre-codes were useful to identify the following categories, the codes, and the codes families, and to aggregate codes that could best explain and represent the investigated dimensions.

Through this process, the first HU generated 23 codes, from 103 total quotations focusing on generic skills referred by students in their personal texts. The codes were aggregated into the 7 following codes families referring to the literature analysis.

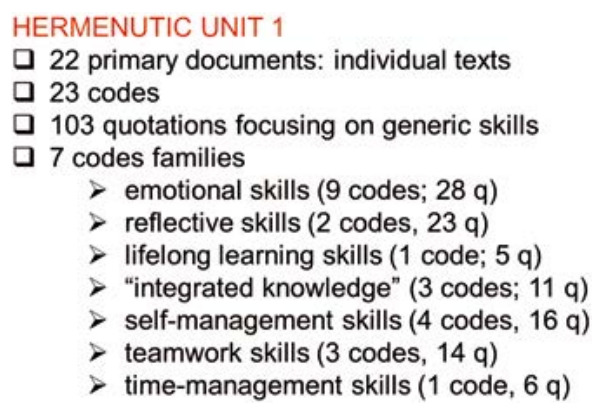

\section{Figure 1}

Hermeneutic Unit 1: code families, codes, quotations

First, we identified a category of generic skills referred to emotional intelligence mentioned by De Villiers. ${ }^{40}$ We defined this first category as emotional skills (9 codes; 28 quotations), which referred to feelings and emotions related to the WR experience and its management by pairs of students. The students clearly exhibited emotions and the strategies in order

${ }^{40}$ De Villiers, "The incorporation of soft skills into accounting curricula." 
to help accommodate their needs while effectively carry out the assignment. According to the students' reflections, the WR activity was rich of emotions: positive ones (14 quotations), including excitement, astonishment to visit the organization, and curiosity, and negative ones (14 quotations), including anxiety and uncertainty. Students referred of an initial feeling of embarrassment and disorientation (8 quotations), worry, and anxiety (3 quotations), they mentioned also their effort to deal with this frustration, supported by the positive welcome of the company, the curiosity toward a new experience and the feeling to have the "opportunity" to observe a real environment.

A second category of skills is related to reflective skills ${ }^{41}$ ( 2 codes, 23 quotations) which refers to reflections on the observation exercise (11 quotations) and on the learning experience in itself (12 quotations). For example, "I have reached a more aware, situated and internalized learning compared with theoretical learning", a student underlined. Another student highlighted, "we had the chance to enrich and improve our skills, without remaining closed in our own system of beliefs or usual patterns". Concerning the observation exercise, it emerged that the WR activity allowed students to reflect on the role of the observer and to go deeper in this process. The content analysis highlighted important references to emotions and feelings related to the interaction with a "real environment". Students seemed to overcome feeling of unfamiliarity and became comfortable with the organizational setting: anxiety and worry prevailed at the beginning of the experience. However, the reports referred that the students were able to pass this emotional obstacle by focusing on their own positive attitudes such as humility and curiosity. Some of the students expressed gratitude for being in a real work context as well as observing a real work setting during worktime.

A third category of generic skills is related to self-management skills ${ }^{42}$ (4 codes, 16 quotations). In their reports, students underlined that the WR experiences encouraged self-management skills in terms of find strategies in order to be well informed about the company before their visit (4 quotations), organizing a way to gather data (7 quotations), identifying the best strategy to carry out the assignment ( 3 quotations), and, finally, being careful to not disturb the routine work (2 quotations). For example, one student specified

${ }^{41}$ Chris Eames and Beverley Bell, "Using sociocultural views of learning to investigate the enculturation of students into the scientific community through work placements," Canadian Journal of Math, Science \& Technology Education 5, no. 1 (2005): 153-169.

${ }^{42}$ Freudenberg, Brimble, and Cameron, "WIL and generic skill development." 
his/her observation strategy: "I decided to photograph spaces and furniture, to focus on some details, but to continue to write down what most impressed me". Another student regarding his/her personal strategy stated "I decided to primarily take notes of my personal impression". A third student explained "I avoided interfering on what I observed, I just took pictures and notes, to respect people in the space". Indeed, students addressed a marked respect to the employees, focused on their daily work and made conscious decisions to intentionally not interfere with the routine of employees. This code was deeply associated with the code: strategy to gathered data. Overall, students adapted their data collection methods in order to be mindful and not disturb the "company life".

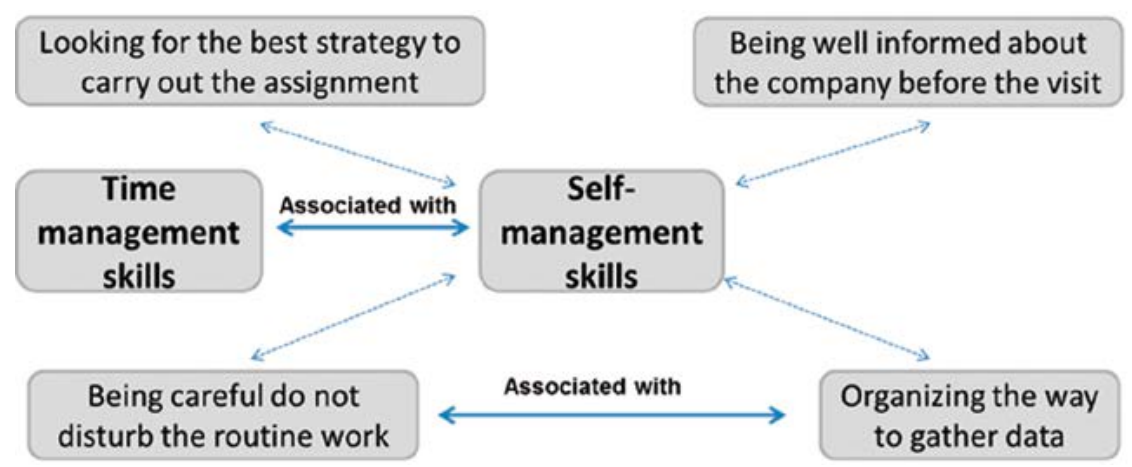

Figure 2

Code family "Self-management skills" and linked codes

A fourth code family referred to teamwork skills ( 3 codes, 14 quotations), another skill set underlined among the generic skills fostered by WRL activities. Students expressed different ways to manage the work in pairs referring to cooperation between the pair work (4 quotations), team decision making referring to the chosen strategy about how to observe, what and when (7 quotations), and sharing of information and observed elements useful to carry out the observation assignment (3 quotations). One student mentioned collaborating with a colleague in order to identify gaps in observations by stating, "during the observation we compared our work in order to integrate observed elements lost by one of us". 


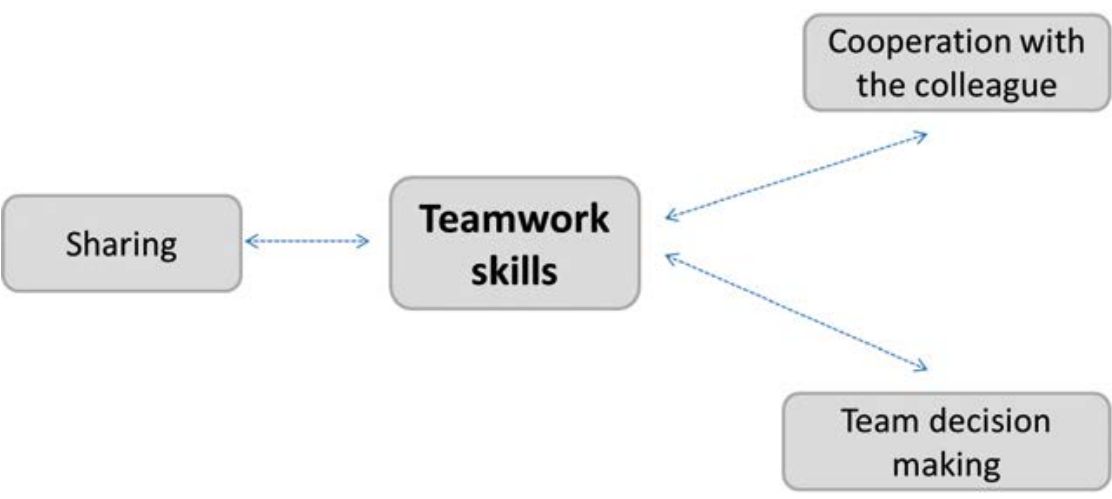

Figure 3

Code family "Teamwork skills" and linked codes

A fifth category of generic skills is "integrated knowledge" ( 3 codes; 11 quotations), which referred to the integration among theory and practice (7 quotations), and past and present learning (1 quotations). Students described the WR experience as a way to transfer theoretical contents in a professional context (3 quotations). A student expressed that, "it was, for me, a guided experience to learn and collect information from the setting, useful to become an educator". Another student mentioned, "I realized that having a critical ability of observation is an important skill for an educator". The content analysis underlined an association between the focus on the transferability of theoretical content in the workplace and the integration theory-practice.

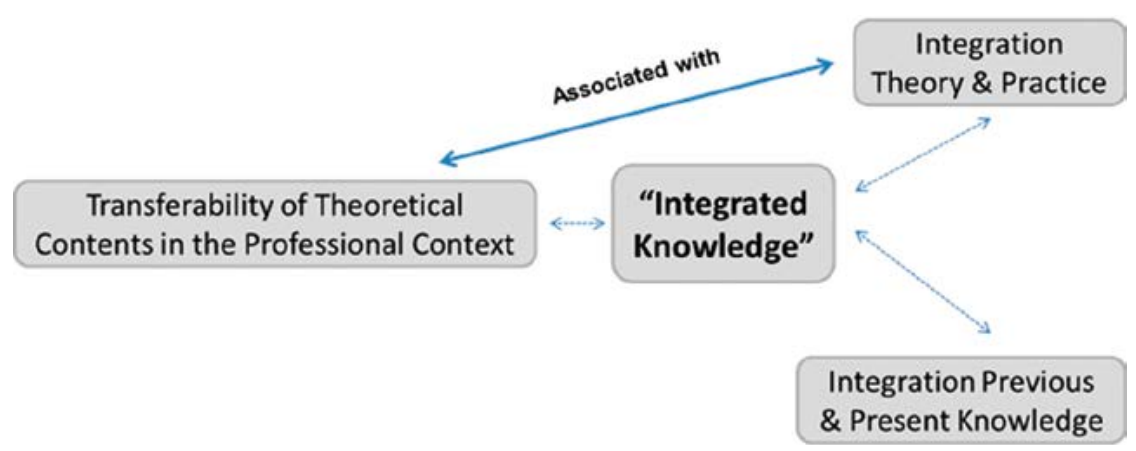

Figure 4

Code family "Integrated Knowledge" and linked codes 
The earlier mentioned self-management skills are strongly associated with a sixth skills family recognized by literature, the time-management skills $^{43}$ ( 1 code, 6 quotations), sometimes included within the self-management skills category, but also recognized independently. Since students addressed specific reflections to time-management skills, the research team decided to include them in a specific category. Students emphasized their efforts to handle time management constraints in order to complete their task and optimize, as much as possible, the time spent in the organizational environment. For instance, one student stated, "we optimized the timework and contributed to the written work in a productive way".

The last category referred to the lifelong learning skills ( 1 code; 5 quotations) concerning the willingness to learn. ${ }^{44}$ Students described their attitude toward the WR activity highlighting their willingness to immerse themselves into the learning experience and to learn from it. One student stated: "I positioned myself in front of the people of the company like a person who needs to learn a lot of things and I actively listened to them".

In order to expand the analysis, we also took into account the 11 reports, written by each student pair, that focuses on the strategy to manage the observation assignment. This second HU generated 9 codes, from 91 total quotations devoted to generic skills referred by the student pairs.

\section{HERMENUTIC UNIT 2}

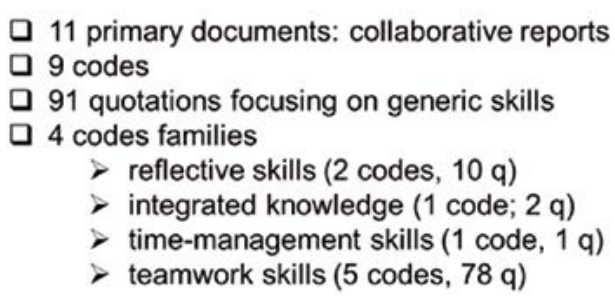

\section{Figure 5}

Hermeneutic Unit 2: code families, codes, quotations

Only four generic skill sets (code families) were mentioned by students in the collaborative part, the most part evidently related to teamwork skills.

${ }^{43}$ Coll and Zegwaard, "Perceptions of desirable graduate competencies."

${ }^{44}$ Devadason, Subramaniam, and Daniel, "Final year undergraduates' perceptions"; Shakir, "Soft skills at the Malaysian institutes of higher learning." 
First, the most mentioned skill set referred to teamwork skills (5 codes, 78 quotations). This collaborative section is strongly devoted to the strategy to work together in order to carry out the assignment in an effective way. In addition to the codes mentioned above (cooperation, team decision making and sharing), a new code appeared, that referred to the comparison (4 quotations) between the different observation strategies and data collection techniques that were chosen by the two members of the work-pair. In fact, the students compared their personal strategy in order to develop an effective way to collect data and carry out the observation exercise. It is interesting to mention that in the previous Hermeneutic Unit, the strategy to collect data was a personal choice and decision. On the other hand, in this second unit the code "organizing the way to gather data" referred to a joint decision between pairs of students and was included in the self-management skills family. Furthermore, the content analysis underlined a strongly association between the three codes: comparison, team decision making and, indeed, organizing the way to gather data.

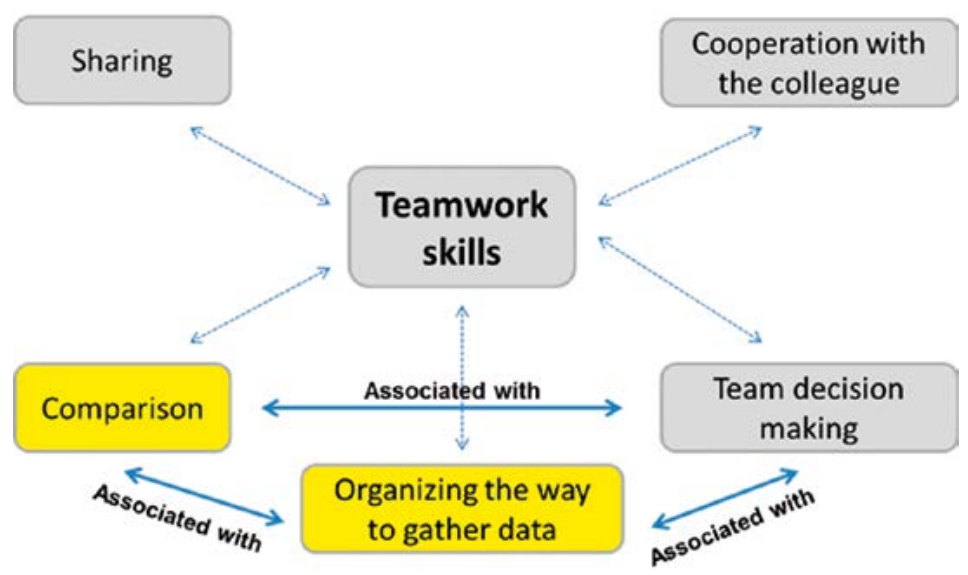

Figure 6

Code family "Teamwork skills" and linked codes

Second, students mentioned reflective skills ( 2 codes, 10 quotations). Once again, the students' reflections focused on the observation exercise (8 quotations) as well as on the learning experiences (2 quotations) as mentioned before concerning the individual texts. 
Third, students referred to what we early identified as "integrated knowledge" ( 1 code, 2 quotations). In this part of the report, students underlined the connection among theory and practice, but the reference to this "integration" is less evident in this part of the assignment. Furthermore, the code "integration between past and present learning", identified in the personal reflection, does not appear in this section.

Fourth, time management skills ( 1 code, 1 quotation) is the last identified family referring to the difficulty to deal with time constraints, but in this second Hermeneutic Unit, this code appears just once. It seems that time is perceived much more as a personal constraint rather than a pair constraint shared between student pairs.

\section{Theoretical Considerations and Recommendations for Practice}

As mentioned above, literature highlights the development of generic skills as one of the main results of WRL strategies and activities. The strong references to generic skills stated by the students involved in the presented WR assignment seems to agree with the literature analysis. Above all, students referred to the emotional, reflective, self-management, and teamwork skills. The content analysis highlights an important reference to emotions and feelings related to the contact with the "real environment".

Reflection emerged as a crucial skill that enables students to identify strengths, difficulties, and challenges of the WR assignment and to face with them. Reflection is central in order to connect theory and practice, understand the links between present and previous knowledge, that students made explicit in their individual texts (for example they mentioned theories and authors studied in previous courses). Self-management and teamwork skills set are as many represented in the content analysis.

The assignment was meant both as individual student and a pair student task. This required students, on one hand, to identify a personal work strategy and observation strategy while on the other hand, share and negotiate a collaborative way of working in order to produce a report that can be delivered to the company. The skill sets for students to work independently and collaborative focused on generic skills development including skills such as self-management and teamwork. However, it would be interesting to see if students develop these same generic skills without being exposed to the same crucial experience of interacting with a real company environment and real customers. In other words, does the experience gained by students working together in a collaborative observation process, where they interact 
with a real work environment with real customers and expectations to deliver a real output, foster the development of generic skills including, but not limited to, self-management and teamwork?

This study offers methodological considerations that can be used to design work-related activities that would foster the development of generic skills when implemented in an academic course.

First, adding a dimension of reality and concreteness to an assignment helps teachers to amplify the outcomes of the learning experience. Even if time spent in the professional context by the students is limited (here, we refer to a unique business visit), in this study the mentioned generic skills are the same usually reported by students involved in an internship or workplacement experience.

Second, to interact with a real customer (not only a real problem, as it occurs in problem-based learning assignment for example, but also a real customer to whom the reports were addressed) amplifies student engagement in this assignment exercise. The consequences of the work experience were not just a negative or positive grade. The consequences refer to the personal "reputation" of students in the professional network. A limitation in this assignment was the lack of opportunity for students to return the reports to company's representatives and receive face to face feedback. In other words, the students' outputs were sent to the Human Resources manager but students did not have the opportunity to receive personal feedback face to face after presenting their reports.

Third, a crucial role for students was being engaged in reflection. It would be possible to only ask students the results of the observation process (the values of the organizational culture "observed using the spaces observation grid) without a reflection on the process. In this study, it is evident that the references to generic skills emerge in the collaborative and individual reflective sections, not in the core part of the assignment referred to the observation of the physical company's setting and focused on the observation output.

Fifth, the arrangement of a work-related assignment asks teachers to take care of the partnership with organizations. Without a clear "contract" which defines tasks and responsibilities of the three implicated subjects - university/ instructors, students, and organizations - the WR activities risk to fail without achieving formative objectives, neither for the academic side, nor for the organization. ${ }^{45}$

\footnotetext{
${ }^{45}$ Frison, "Esperienza e apprendimento;" Frison, Fedeli and Taylor, "Work-Related Learning."
} 
Sixth, a crucial aspect of WR strategies is support. Students have to be supported and encouraged by both parties involved, the university and organization. Therefore, every WR activity must offer time and space of support, a sort of "help" service which welcomes administrative and organizational problems, offering a "learning guide" to the students to deal with critical situations. Reflective spaces and tools, monitoring meeting, and peer-tutoring meeting have this aim. ${ }^{46}$ In this specific case, an online tutor supported students starting from the business visit day, to the final delivery of the output, facilitating the collaborative assignment process.

In the end, assessment and integration are two crucial aspects of WR strategies, and they must be considered within the curriculum. These dimensions open to new questions. For instance, how can teachers assess WR experiences? If not teachers, then who assesses these experiences? Should the university, the organization, or perhaps both collaborative assess WR experiences? Nevertheless, WRL is known to rely on the university for new assessment strategies more oriented to assess skills and competences rather than knowledge..$^{47}$

\section{Further Steps and Conclusions}

This study offers just a first exploration on how to encourage WR activities in order to foster generic skills and it highlights the crucial role of the company in carrying out of the assignment.

A further analysis is in progress, concerning the reflections offered by a new group of students involved in a similar observation exercise during the academic year 2015/2016. A new element was added: the Human Resources manager of the company (a new one, different from that one of the academic year 2014/2015) analysed the students' reports and provided in-depth feedback in person, during the final lesson. Furthermore, the students' analysis of the organizational values was shared within the company and communicated to the ownership. The collected data are going to be analysed and compared.

Furthermore, it would be interesting to compare the same assignment carried out without a "real" customer and a "real" workplace (for example

${ }^{46}$ Cooper, Orrell, and Bowden, "Work integrated learning;" Frison, Fedeli and Taylor, "Work-Related Learning;" Litchfield, Frawley, and Nettleton, "Work-ready wiki."

${ }^{47}$ Cooper, Orrell, and Bowden, Work integrated learning; Gardner and Bartkus, "What's in a name?". 
the observation of the academic spaces or other public space) in order to analyse if emotional, self-management, and teamwork skills are emphasized differently than in cases with a "real" customer and workplace.

In the end, this data will be valued to arrange a specific professional development path on work-related strategies in higher education, to encourage the proposal of work-related activities and assignments in classrooms, and to enhance teachers' recognition and appreciation for the centrality of generic skills during the academic experience.

\section{Bibliography}

Abeysekera, Indra. "Issues relating to designing a Work-Integrated Learning (WIL) program in an undergraduate accounting degree program and its implications for the curriculum." Asia-Pacific Journal of Cooperative Education 7, no. 1 (2006): 7-15.

Atchison, Mary, Sarah Pollock, Ern Reeders, and Janine Rizzetti. Work integrated learning paper. Melbourne: RMIT University (2002).

Bennett, Neville, Elisabeth Dunne, and Clive Carré. "Patterns of core and generic skill provision in higher education." Higher education 37, no. 1 (1999): 71-93.

Bridgstock, Ruth. "The graduate attributes we've overlooked: Enhancing graduate employability through career management skills." Higher Education Research \& Development 28, no. 1 (2009): 31-44

Burchell, Noel, Dave Hodges, and L. Rainsbury. "What competencies do business graduates require? Perspectives of New Zealand stakeholders." Journal of Cooperative Education 35, no. 2-3 (2000): 11-20.

Cannan, James. "Practice based learning: exploring current models used for real world learning at a "dual sector tertiary institution"." WACE Asia Pacific Conference E-Proceedings (2008): 91-97.

Commission of the European Communities. A new partnership for the modernisation of universities: the EU Forum for University Business Dialogue, 2009. Accessed July 22, 2016. http://ec.europa.eu/transparency/regdoc/recherche.cfm?C=it.

Coll, Richard K., Chris Eames, Levinia Paku, Mark Lay, Diana Ayling, Dave Hodges, Shiu Ram, Ravi Bhat, Jenny Fleming, Lesley Ferkins, Cindy Wiersma, and Andrew Martin. "Putting the 'integrated' in work-integrated learning." In World Association of Co-operative Education Asia Pacific 2008 Conference: Work Integrated Learning (WIL): Transforming Futures, Practice...Pedagogy... Partnerships (2008): 101-107.

Coll, Richard K., and Karsten E. Zegwaard. "Perceptions of desirable graduate competencies for science and technology new graduates." Research in Science \& Technological Education 24, no. 1 (2006): 29-58.

Cooper, Lesley, Janice Orrell, and Margaret Bowden. Work integrated learning: A guide to effective practice. Routledge, 2010. 
Crebert, Gay, Merrelyn Bates, Barry Bell, Carol-Joy Patrick, and Vanda Cragnolini. "Developing generic skills at university, during work placement and in employment: graduates' perceptions." Higher Education Research \& Development 23, no. 2 (2004): 147-165. http://dx.doi.org/10.1080/0729436042000206636

Devadason, Evelyn Shyamala, Thirunaukarasu Subramaniam, and Esther Gnanamalar Sarojini Daniel. "Final year undergraduates' perceptions of the integration of soft skills in the formal curriculum: a survey of Malaysian public universities." Asia Pacific Education Review 11, no. 3 (2010): 321-348.

De Villiers, Rouxelle. "The incorporation of soft skills into accounting curricula: preparing accounting graduates for their unpredictable futures." Meditari Accountancy Research 18, no. 2 (2010): 1-22.

Dirkx, John M. "Work-Related Learning in the United States: Past Practices, Paradigm Shifts, and Policies of Partnerships." The Sage Handbook of Workplace Learning (2011): 293-306.

Drummond, Ian, Iain Nixon, and John Wiltshire. "Personal transferable skills in higher education: The problems of implementing good practice." Quality assurance in education 6, no. 1 (1998): 19-27.

Eames, Chris, and Beverley Bell. "Using sociocultural views of learning to investigate the enculturation of students into the scientific community through work placements." Canadian Journal of Math, Science \& Technology Education 5, no. 1 (2005): 153-169.

Eyler, Janet. "The power of experiential education." Liberal Education 95, no. 4 (2009): 24-31.

European Commission. Supporting growth and jobs - an agenda for the modernisation of Europe's higher education systems, 2011. Accessed July 22, 2016. http://ec.europa.eu/education/library/policy/modernisation_en.pdf.

- Modernisation of Higher Education. Report on Improving the quality of teaching and learning in Europe's higher education institutions. Luxembourg: Publications Office of the European Union, 2013. Accessed July 22, 2016. http:// ec.europa.eu/education/library/reports/modernisation_en.pdf.

Freudenberg, Brett, Mark Brimble, and Craig Cameron. "It's All about'I': Implementing 'Integration' into a WIL Program." eProceedings of the WACE Asia Pacific Conference, 2009. Accessed July 22, 2016. http://acen.edu.au/resources/docs/ WACE_ACEN_Asia_Pacific_Conference_2008_E-Proceedings-1. pdf\#page $=170$.

- "Where there is a WIL there is a way." Higher Education Research \& Development 29, no. 5 (2010): 575-588.

- "WIL and generic skill development: The development of business students' generic skills through work-integrated learning." Asia-Pacific Journal of cooperative education 12, no. 2 (2011): 79-93.

Frison, Daniela. "Esperienza e apprendimento: verso una didattica work-related". In Coinvolgere per apprendere. Metodi e tecniche partecipative per la formazione, edited by Monica Fedeli, Valentina Grion, and Daniela Frison, 259-288. Lecce: Pensa Multimedia, 2016. 
Frison, Daniela, Monica Fedeli, and Edward W. Taylor. "Work-Related Learning: a survey on Teaching and Learning Methods in the Italian Higher Education System.” ICERI 2015 Proceedings, (2015): 8393-8401.

Gardner, Phil, and Kenneth R. Bartkus. "What's in a name? A reference guide to work-education experiences." Asia-Pacific Journal of Cooperative Education 15, no. 1 (2014): 37-54.

Kearns, Peter. Generic Skills for the New Economy. Review of Research. Leabrook: National Centre for Vocational Education Research, 2001.

Lee, Scott. "A comparison of student perceptions of learning in their co-op and internship experiences and the classroom environment: A study of hospitality management students". Diss., University of Central Florida Orlando, Florida, 2006.

Litchfield, Andrew, and Nettleton Skye. "Work-ready wiki: Supporting the learning and teaching of professional graduate attributes." Hello! Where are you in the landscape of educational technology? Proceedings of Ascilite Melbourne (2008): 552-561.

Mayer, Eric. Putting general education to work: The key competencies report. Canberra: Australian Education Council and Ministers for Vocational Education, Employment and Training, 1992.

McLennan, Belinda, and Shay Keating. "Work-integrated learning (WIL) in Australian universities: The challenges of mainstreaming WIL." ALTC NAGCAS National Symposium, 2008. Accessed July 22, 2016. http://citeseerx.ist.psu.edu/ viewdoc/download?doi=10.1.1.530.4443\&rep=rep1\&type=pdf

Merriam, Sharan B., and Elizabeth J. Tisdell. Qualitative research: A guide to design and implementation. John Wiley \& Sons, 2015.

Munari, Aberto. "L'osservazione sistematica e strutturata della gestione degli spazi di un'organizzazione". Unpublished manuscript, University of Padova, Italy, 2013.

Nealy, Chynette. "Integrating soft skills through active learning in the management classroom." Journal of College Teaching \& Learning (TLC) 2, no. 4 (2011): 1-6.

Sambrook, Sally. "Factors influencing the context and process of work-related learning: Synthesizing findings from two research projects." Human Resource Development International 8, no. 1 (2005): 101-119.

Scott, John L., and Michelle Sarkees-Wircenski. Overview of Vocational and Applied Technology Education. Homewood Illinois: American Technical Publishers, 2004.

Shakir, Roselina. "Soft skills at the Malaysian institutes of higher learning." Asia Pacific Education Review 10, no. 3 (2009): 309-315.

Subramaniam, Nava, and Brett Freudenberg. "Preparing accounting students for success in the professional environment: Enhancing self-efficacy through a work integrated learning programme." Asia-Pacific journal of cooperative education 8, no. 1 (2007): 77-92.

Technopolis. Education in the Knowledge Triangle, 2012. Accessed July 22, 2016. http://www.mondragon.edu/en/international/files/OF\%2035\%201613\%20 Draft $\% 20$ final\%20report\%20and\%20case\%20studies\%20121025-1.pdf. 
Weber, Melvin R., Dori A. Finley, Alleah Crawford, and David Rivera, Jr. "An exploratory study identifying soft skill competencies in entry-level managers." Tourism and hospitality Research 9, no. 4 (2009): 353-361.

\section{About the Authors}

DANIELA FRISON (daniela.frison@unipd.it), PhD in Educational Sciences at University of Padova (2012), is currently Post-Doc Researcher at the Department of Philosophy, Sociology, Education, and Applied Psychology, University of Padova. She is coordinator of the project PARIMUN: a University-Enterprise Alliance to Promote Widespread Expertise which aims at developing intervention-research projects starting from business needs and carried out by graduating students in Educational Sciences. She teaches "Methodology of Training" and "Intervention-Research Strategies". Her current interests include: university-business cooperation, teaching and learning methods in higher and adult education, with a specific focus on work-related learning. She is member of the project team of two Erasmus+ projects: REFLECT - Reflection as core transferable competence in higher education and adult education, University of Vilnius, Lithuania (2014-2016) and COMPALL - Comparative Studies in Adult and Lifelong Learning, Julius Maximilian University of Würzburg, Germany (2015-2017). She is member of the Young Scientist Committee of the international book series: Adult learning strategies, methods and contexts.

CONCETTA TINO (concettatino8@gmail.com), is a doctoral student at University of Padova (Italy). Her main fields of research are the School-Work Alternation programs as part of Work-Based Learning experiences, and the training of teachers-tutor involved in supporting students in the transition school-to-work. At the moment she is spending two months at University of Georgia for her research. She has participated to two Erasmus+ projects: REFLECT - Reflection as core transferable competence in higher education and adult education, University of Vilnius (2014-2016) and COMPALL - Comparative Studies in Adult and Lifelong Learning, Julius-Maximilian-University of Würzburg, Germany. (2015-2017). She participated in the last two years at International Winter school- Comparative studies on Adult and Lifelong Learning Julius Maximilian University of Würzburg, Germany.

JONATHAN W. TYNER (jonathantyner@txstate.edu), is a doctoral student in the Adult, Professional, and Community Education program at Texas State University. His current position is the international engagement specialist for Texas State University in San Marcos, Texas. His research interests are focused on international education, international student mobility, international student motivation, faculty professional development, work-related teaching and learning, and internationalizing the curriculum through cultural inclusion and pedagogical adaptation. In regards to work-related learning experiences, he has worked on appreciative inquiry projects with community based non-profit 
organizations, conducted qualitative research that interviewed business managers and organizational leaders in order to obtain their perspective on the values and necessity for work-related learning and continued education, led professional developments that integrate work-related teaching and learning for higher education administrators and student affairs professionals, as well as recently published a book review in the Australian Journal of Adult Learning that discusses teaching international students in vocational education.

MONICA FEDELI (monica.fedeli@unipd.it), PhD in Teaching and Learning and Special Education, is currently Associate Professor at University of Padova, where she is Program Coordinator of the MD course: Management of Educational Services and Continuing Education and Advisor for Faculty Development and Didactic Innovation. She has been Adjunct Professor at Michigan State University. U.S.A., at Julius Maximilians University of Wurzburg, Germany and Visiting research and professor at Boston University, School of Education and at California University Berkeley School of Education. Her current interests include: participatory teaching and learning in higher education, reflection and learning, organization development, faculty development and faculty development in international settings. She published more than 60 articles, books and book chapters in variety of national and international journals: Adult Learning, Educational Reflective Practices, Giornale Italiano della Ricerca Educativa and in a variety of book series. She is member of the steering committee of the journal: Educational Reflective Practices, Co-editor of the International Journal: Excellence in Teaching and Learning; and of the international book series: Adult learning strategies, methods and contexts. She is leading as principal investigator specific national and international projects designed to develop research and facilitate networking, including agreements with several American and European universities. 


\section{Work-related teaching and learning methods to foster generic skills in Higher Education. An Italian experience}

Daniela Frison, Concetta Tino, Jonathan W. Tyner, and Monica Fedeli*

\section{Copyright}

Copyright for this article is retained by the Publisher. It is an Open Access material that is free for download, distribution, and or reuse in any medium only for non-commercial purposes; provided any applicable legislation is respected, the original work is properly cited, and any changes to the original are clearly indicated. 